\title{
AN APPEAL BY AMERICAN SCIENTISTS TO THE GOVERNMENTS AND PEOPLE OF THE WORLD
}

We, the American scientists whose names are signed below, urge that an international agreement to stop the testing of nuclear bombs be made now.

Each nuclear bomb test spreads an added burden of radioactive elements over every part of the world. Each added amount of radiation causes damage to the health of human beings all over the world and causes damage to the pool of human germ plasm such as to lead to an increase in the number of seriously defective children that will be born in future generations.

So long as these weapons are in the hands of only three powers an agreement for their control is feasible. If testing continues, and the possession of these weapons spread to additional governments, the danger of outbreak of a cataclysmic nuclear war through the reckless action of some irresponsible national leader will be greatly increased.

An international agreement to stop the testing of nuclear bombs now could serve as a first step toward a more general disarmament and the ultimate effective abolition of nuclear weapons, averting the possibility of a nuclear war that would be a catastrophe to all humanity.

We have in common with our fellow men a deep concern for the welfare of all human beings. As scientists we have knowledge of the dangers involved and therefore a special responsibility to make those dangers know. We deem it imperative that immediate action be taken to effect an international agreement to stop the testing of all nuclear weapons.

$\begin{array}{lll}\text { Linus Pauling } & \text { Martin Kamen } & \text { Severo Ochoa } \\ \text { Barry Commoner } & \text { Edwin C. Kamble } & \text { C. C. Price } \\ \text { Edward U. Condon } & \text { I. M. Kolthoff } & \text { Arthur Roberts } \\ \text { Charles D. Coryell } & \text { Chauncey Leake } & \text { M. L. Sands } \\ \text { Leslie C. Dunn } & \text { S. E. Luria } & \text { Verner Schomaker } \\ \text { Viktor Hamburger } & \text { Max Mason } & \text { Laurence H. Snyder } \\ \text { Michael Heidelberger } & \text { Carl V. Moore } & \text { Oswald Veblen } \\ \text { I. H. Herskowitz } & \text { Philip Morrison } & \text { M. B. Visscher } \\ \text { Herbert Jehle } & \text { Herman J. Muller } & \text { W. H. Zachariasen }\end{array}$

\section{ON THE APPEAL OF AMERICAN SCIENTISTS TO STOP NUCLEAR WEAPON TESTS}

\author{
TIBOR KOLBENHEXER \\ Dept. of Mining Geodesy and Geophysics, Institute of technology, Košice*)
}

In this critical period, when the whole of mankind rightly fears for the future which is threatened with the great danger of an atomic war, scientific workers the world over bear an unusually great responsibility for the fate of human society. It was science which gave man atomic energy and it is therefore the moral duty of every honest scientific worker to fight so that the tremendous discoveries in the field of atomic research should not become the criminal

*) Address: Rektorát VST, Zbrojnická 7, Košice. 